\title{
Mineral supplementation stimulates the immune system and antioxidant responses of dairy cows and reduces somatic cell counts in milk
}

\author{
AMANDA C. WARKEN ${ }^{1}$, LEANDRO S. LOPES ${ }^{1}$, NATHIELI B. BOTTARI', \\ PATRÍCIA GLOMBOWSKY ${ }^{3}$, GABRIELA M. GALLI ${ }^{3}$, VERA M. MORSCH ${ }^{2}$, \\ MARIA ROSA C. SCHETINGER ${ }^{2}$ and ALEKSANDRO S. DA SILVA ${ }^{1}$ \\ ${ }^{1}$ Programa de Pós-Graduação em Zootecnia, Universidade do Estado de Santa Catarina /UDESC, \\ Rua Beloni Trombeta Zanin, 680E, Santo Antônio, 89815-630 Chapecó, SC, Brazil \\ ${ }^{2}$ Departamento de Bioquímica e Biologia Molecular, Universidade Federal de Santa Maria/UFSM, \\ Av. Roraima, 1000, 97105-900 Santa Maria, RS, Brazil \\ ${ }^{3}$ Departamento de Zootecnia/UDESC, Rua Beloni Trombeta Zanin, 680E, Santo Antônio, 89815-630 Chapecó, SC, Brazil
}

Manuscript received on July 10, 2017; accepted for publication on October 4, 2017

\begin{abstract}
The aim of this study was to evaluate whether the use of subcutaneous mineral supplementation would affect metabolic parameters, immunological response, milk quality and composition of dairy cows in the postpartum period. Twelve pregnant primiparous Holstein cows, were divided into two groups: six animals supplemented with the mineral complex (magnesium, phosphorus, potassium, selenium and copper), and six animals used as controls. Milk samples were collected every two other weeks postpartum up to sixty days of lactation to analyze composition and quality. Blood samples were collected, and the levels of ketone bodies, total proteins, glucose, albumin, and globulin were measured. The catalase and superoxide enzymes, reactive oxygen species, tumor necrosis factor, and interleukins were determined. Animals supplemented with minerals showed lower levels of ketone bodies and somatic cell counts on days 30, 45 and 60 of the experiment, without changes in milk composition compared to the control group. Supplemented cows had lower levels reactive oxygen species and increased superoxide enzymes activity. Total protein, globulin and cytokine levels were higher in cows supplemented with mineral complexes. Therefore, we can conclude that subcutaneous mineral supplementation improved the immune response and minimized the oxidative stress in dairy cows during lactation.
\end{abstract}

Key words: cattle, ketone bodies, mineral supplementation, somatic cell count, health.

\section{INTRODUCTION}

Milk cattle farming is constantly growing and is considered an important activity with economic

Correspondence to: Leandro Sâmia Lopes

E-mail: leandrosamia@uol.com.br

Aleksandro Schafer da Silva

E-mail: dasilva.aleksandro@gmail.com interest in the world. However, nutritional strategies are necessary to improve animal health and to reduce losses in milk production. The transition period (3 weeks pre-calving to 3 weeks post-calving) is considered a critical period for lactating dairy cows and primary attention should be developing to nutritional management in the post-calving period, 
since this is related to low intake of dry matter (DM) and a high energy demand to keep milk production, which may lead to a negative energy balance for the animal (Esposito et al. 2014). The transition period may cause physiological alterations, as the oxidative stress, characterized by high free radical formation in the bloodstream, affecting the normal metabolism (Sordillo 2016). In the postcalving period, the increase in lipid peroxidation occurs due to a greater mobilization of body fat as a result of the lower intake of dry matter and greater nutritional requirement for milk producion (Wathes et al. 2007).

During the transition period there is a normal response to free radical formation in the body through antioxidants enzymes which are regulated by minerals. The minerals play a key role in the immune and reproductive systems and in the growth of dairy cows (Shankar and Prasad 1998). Selenium, for example, is a mineral with an antioxidant function, capable of reducing the production of free radicals through the activation of the enzyme glutathione peroxidase. Therefore, studies with selenium supplementation demonstrated a reduction in the incidence of mastitis and somatic cell counts (SCC) in cattle (Overton and Yasui 2014), as well as increased erythrocyte and neutrophil production in the bloodstream (Morgante et al. 1999). Copper is another mineral with important function in the immune system, acting in several defense cells (neutrophils, monocytes and T cells) and activating the enzyme superoxide dismutase (SOD), an antioxidant enzyme that catalyzes the dismutation of superoxide into oxygen and hydrogen peroxide as a mechanism to reduce free radicals (Wintergerst et al. 2007).

The mineral intake during the transition period is importent for cows. In this way, the application of injectable minerals could be an alternative to diet supplementation. Some studies have demonstrated the benefits of injectable minerals in the immune response, reducing $\beta$-hydroxybutyrate (BHBA) concentration, increasing SOD enzymatic activity, and promoting the reduction of clinical mastitis and SCC of dairy cows (Machado et al. 2014, Ganda et al. 2016). In addition, recently our research group found in a previous study that cows supplemented with injectable minerals had stimulation of the immune response and increased activity of antioxidant enzymes (Soldá et al. 2017). Thus, the purpose of this study was to evaluate whether the use of subcutaneous mineral supplementation would affect metabolic parameters, immunological and antioxidant responses, in addition to milk composition and quality of dairy cows in the postcalving period.

\section{MATERIALS AND METHODS}

\section{ETHICAL COMMITTEE}

The present study was approved by the Ethics Committee for Use of Animals (CEUA) of Universidade do Estado e Santa Catarina (UDESC), under protocol number 477713101.

\section{ANIMALS}

The study was conducted in a commercial free-stall dairy farm located in Chapecó city, Southern Brazil. The farm had approximately 120 lactating animals, with an average of milk production of 25 liters/ day. From these, 12 primiparous Holstein cows, with average weight of $450 \pm 50 \mathrm{~kg}$ and age of approximately $26 \pm 1$ months were selected for this study. The diets provided for pre and post-calving cows, as well as the chemical analyses are shown in Table I. For pre-calving cows the dry matter intake cow/day was $5.91 \mathrm{~kg}$ of roughage and $3.76 \mathrm{~kg}$ of concentrate $(61 \%$ and $39 \%)$, and for cows postcalving, the dry matter intake cow/day was 8.42 $\mathrm{kg}$ of roughage and $8.04 \mathrm{~kg}$ of concentrate $(51 \%$ and $49 \%$ ), respectively. The animals were fed $a d$ libitum twice a day, always after milking. During the experimental period, both groups were housed in a covered shed with free access to water. 
TABLE I

Ingredients and chemical composition of the experimental diets.

\begin{tabular}{ccc}
\hline Composition & $\begin{array}{c}\text { Pre-calving } \\
\text { (kg/DM) }\end{array}$ & $\begin{array}{c}\text { Post-calving } \\
\text { (kg/DM) }\end{array}$ \\
\hline Corn silage & 2.81 & 7.02 \\
Tifton hay & 1.31 & 0.0 \\
Tifton pre-dried & 0.0 & 1.4 \\
Ground corn & 0.88 & 3.08 \\
Soybean meal & 2.23 & 4.46 \\
Wheat bran & 1.79 & 0.0 \\
Mineral & 0.20 & 0.50 \\
Feed Intake (kg/day) & 9.67 & 16.46 \\
\hline Chemical Analysis & & \\
\hline CP (\%) & 20 & 20.2 \\
NDF (\%) & 32.4 & 31.3 \\
NDT (\%) & 27.3 & 72.4 \\
Fat (\%) & 2.6 & 2.8 \\
NeL (Mcal/day) & 0.64 & 1.00 \\
Ca (\%) & 0.5 & 0.8 \\
P (\%) & 0.5 & 0.6 \\
Mg (\%) & 0.25 & 0.31 \\
K (\%) & 1.26 & 1.34 \\
Se (mg/day) & $2.39 \mathrm{ppm}$ & $4.5 \mathrm{ppm}$ \\
Cu & $17.64 \mathrm{ppm}$ & $25.68 \mathrm{ppm}$ \\
\hline
\end{tabular}

*Quantity supplied in dry matter (DM). CP, crude protein; NDF, Neutral detergent fiber; NDT, Total digestive nutrients; $\mathrm{NeL}$, net energy for lactation.

\section{EXPERIMENTAL DESIGN}

The experimental design was completely randomized, and the cows were randomly divided into two groups, according to the expected calving day: the supplemented group (animals treated with the subcutaneous mineral supplement) and the control group (without subcutaneous mineral supplementation). The animals in the supplemented group received a dose of $10 \mathrm{~mL} /$ animal (manufacturer's recommended dose) via subcutaneous at three times: approximately 20 days before calving ( $1^{\text {st }}$ dose $)$, on calving day $\left(2^{\text {nd }}\right.$ dose $)$ and 20 days post-calving ( $3^{\text {rd }}$ dose $)$. The mineral complex used in this study is a commercial product (Fosfosal ${ }^{\circledR}$, Virbac, France) with the following composition per $100 \mathrm{~mL}$ : sodium glycerophosphate (5.5H2O: $14 \mathrm{~g})$, monosodium phosphate $\left(2 \mathrm{H}_{2} \mathrm{O}\right.$ : $20,1 \mathrm{~g})$, copper chloride $\left(2 \mathrm{H}_{2} \mathrm{O}: 0.4 \mathrm{~g}\right)$, potassium chloride $(0.6 \mathrm{~g})$, magnesium chloride $(2.5 \mathrm{~g})$ and sodium selenite $(0.24 \mathrm{~g})$.

SAMPLING

Blood samples were collected after calving on days $3,15,45$ and 60 of the experiment, when the main disturbances in the transition period were expected to appear. Blood was collected through the caudal vein and stored in non-anticoagulant tubes to obtain serum. The serum was obtained after blood centrifugation (3.500 rpm for 10 minutes), transferred to Eppendorf tubes, and frozen at -20 ${ }^{\circ} \mathrm{C}$ until analyses. In another tube, the blood was collected with anticoagulant (sodium citrate) to measure catalase and superoxide dismutase activities.

\section{MILK PRODUCTION AND COMPOSITION}

The volume of milk produced was individually measured using a bucket during milking every other week post-calving (days 15, 30, 45 and 60). After milking, a sample of the milk was collected and transferred to a vial with bronopol and refrigerated at $4{ }^{\circ} \mathrm{C}$ until processing. Centesimal composition of fat, protein, lactose, total solids and minerals in milk were analyzed using the infrared method (ISO 9622 - IDF Standart 141C: 2000) and somatic cell counts (SCC) were evaluated using the flow cytometer method 13366-2 - IDF Standard 148-2: 2006).

\section{KETONE BODIES MEASUREMENT}

Levels of blood $\beta$-ketone were measured using specific tapes for quantification of ketone bodies (KetoVet Strip TD-4235®). A small hole with a hypodermic needle was performed in the caudal vein of the animal, and one drop of blood was placed on the tape and immediately read using 
a specific apparatus (KetoVet TD-4235®). The results were expressed as $\mathrm{mmol} / \mathrm{L}$.

\section{BIOCHEMICAL ANALYZES}

The serum concentration of glucose, total proteins and albumin were measured using a commercial kit (Analisa ${ }^{\circledR}$, Carlos Prates, Belo Horizonte, Brazil) according to the manufacturer's instructions and the results read by semi-automatic equipment (Bioplus 2000). The globulin levels were obtained by subtracting the albumin from the total protein.

\section{FREE RADICALS AND ANTIOXIDANTS ENZYMES}

Free radicals (ROS) levels were determined in serum according to the technique described by Ali et al. (1992). Samples were diluted 1:10 with 10 $\mathrm{mM}$ Tris ( $\mathrm{pH}$ 7.4) and $5 \mu \mathrm{l}$ of dichlorofluorescine diacetate (DCFH-DA) as described in detail by Radavelli et al. (2016).

The activity of superoxide dismutase enzyme in whole blood was based on the spectrophotometric assay as described by McCord and Fridovich (1969), and the results were expressed in U SOD/ $\mathrm{mg}$ protein. The catalase activity in whole blood was determined by Nelson and Kiesow (1972), and the results were expressed in nmol CAT/mg protein.

\section{PRO-INFLAMMATORY CYTOKINES LEVELS}

Quantification of cytokines (tumor necrosis factor (TNF), and interleukin 1 and 6 (IL-1 and IL6) was performed using ELISA and commercial kit (Quantikine ${ }^{\circledR}, \mathrm{R} \&$ D Systems, Minneapolis, MN, USA) according to the manufacturer's recommendations.

\section{STATISTICAL ANALYSIS}

The results were submitted to the Shapiro-Wilk test to verify the distribution of the data. The SCC variable did not show normality, and therefore, it was decided to use a non-parametric test, using the independent Kruskal-Wallis test. The other variables were submitted to the Student t-test. The results were considered significant when $\mathrm{P}<0.05$.

\section{RESULTS}

\section{MILK PRODUCTION AND COMPOSITION}

There were no differences $(\mathrm{P}>0.05)$ in milk production between treatments, with a mean of 19.3 vs 22.0 liters (day 15 post-calving), 23.0 vs 24.3 liters (day 30 post-calving), 23.5 vs 24.8 (day 45 post-calving) and 24.2 vs. 26.2 liters (day 60 postcalving) in the cows supplemented with mineral compared to the control group. The centesimal milk composition (fat, lactose, protein, total solids and minerals) did not differ between groups ( $\mathrm{P}>$ 0.05) during the experimental period. The SCC differed between treatments $(\mathrm{P}<0.05)$, with lower SCC values in the animals supplemented with minerals on days 30, 45 and 60 of the study. Milk production and composition, and SCC results are shown in Table II.

\section{KETONE BODIES}

Serum concentrations of ketone bodies differed between treatments at different times throughout the experimental period $(\mathrm{P}<0.05)$. On days 30,45 and 60 post-calving serum concentrations of ketone bodies were lower in animals that have received injectable mineral supplementation compared to the control group (Table III).

\section{SERUM BIOCHEMISTRY}

There was a significant difference $(\mathrm{P}<0.05)$ in seric levels of total protein and globulin between groups at different sampling time. On days 3, 15 and 30 post-calving seric total protein and globulin were higher in animals that received injectable mineral supplementation compared to control animals. However, glucose and albumin concentrations did not differ between groups ( $\mathrm{P}>0.05)$ (Table III).

\section{LEVELS OF FREE RADICALS AND ANTIOXIDANTS ENZYMES}

ROS levels differed between groups $(\mathrm{P}<0.05)$ where animals supplemented with minerals had lower ROS 
TABLE II

Mean and standard deviation of milk production, milk composition and somatic cell counts on days $15,30,45$ and 60 post-calving of dairy primiparous cows supplemented with injectable minerals during the transitional period.

\begin{tabular}{|c|c|c|c|c|}
\hline Variable & Days & Supplemented group & Control group & P-value \\
\hline \multirow[t]{4}{*}{ Milk production $(\mathrm{L})^{*}$} & 15 & $19.3(4.9)$ & $22.0(3.0)$ & $>0.05$ \\
\hline & 30 & $23.0(2.6)$ & $24.3(4.1)$ & $>0.05$ \\
\hline & 45 & $23.5(2.5)$ & $24.8(3.1)$ & $>0.05$ \\
\hline & 60 & $24.2(1.25)$ & $26.2(5.5)$ & $>0.05$ \\
\hline \multirow[t]{4}{*}{ Fat $(\%)^{*}$} & 15 & $3.8(1.1)$ & $3.9(0.5)$ & $>0.05$ \\
\hline & 30 & $3.9(0.8)$ & $4.1(0.7)$ & $>0.05$ \\
\hline & 45 & $3.2(0.2)$ & $3.4(0.9)$ & $>0.05$ \\
\hline & 60 & $3.0(0.6)$ & $3.6(0.7)$ & $>0.05$ \\
\hline \multirow[t]{4}{*}{ Protein $(\%)^{*}$} & 15 & $2.7(0.22)$ & $3.0(0.20)$ & $>0.05$ \\
\hline & 30 & $2.8(0.20)$ & $2.9(0.17)$ & $>0.05$ \\
\hline & 45 & $2.8(0.14)$ & $2.8(0.22)$ & $>0.05$ \\
\hline & 60 & $2.8(0.23)$ & $3.0(0.29)$ & $>0.05$ \\
\hline \multirow[t]{4}{*}{ Lactose $(\%)^{*}$} & 15 & $4.6(0.13)$ & $4.4(0.42)$ & $>0.05$ \\
\hline & 30 & $4.7(0.86)$ & $4.5(0.34)$ & $>0.05$ \\
\hline & 45 & $4.8(0.17)$ & $4.4(0.43)$ & $>0.05$ \\
\hline & 60 & $4.8(0.1)$ & $4.6(0.20)$ & $>0.05$ \\
\hline \multirow{4}{*}{$\begin{array}{l}\text { Somatic cell count } \\
\qquad(\mathrm{x} 1000 / \mathrm{mL})^{* *}\end{array}$} & 15 & $220.3(113)$ & $207.0(176)$ & $>0.05$ \\
\hline & 30 & $49.6(35)$ & $471.2(325)$ & $<0.05^{*}$ \\
\hline & 45 & $36.6(8.4)$ & $867.5(614)$ & $<0.05^{*}$ \\
\hline & 60 & $67.7(55)$ & $497.0(311)$ & $<0.05^{*}$ \\
\hline
\end{tabular}

*Significantly $(\mathrm{P}<0.05)$. Student t-test; ${ }^{* *}$ independent Kruskal-Wallis test.

values on days 15 and 30 post-calving compared to the control animals. Similarly, there was a significant difference $(\mathrm{P}<0.05)$ in SOD enzymatic activity on days 3, 15 and 30 post-calving, where animals that received subcutaneous mineral supplementation had higher values. However, levels of the CAT enzyme showed no differences between the groups $(\mathrm{P}>0.05)$ (Table IV).

\section{PRO-INFLAMMATORY CYTOKINES LEVELS}

There were significant differences $(\mathrm{P}<0.05)$ in $\mathrm{TNF}$ and IL-1 cytokines on days 15 and 30 post-calving, where higher levels of these cytokines were found in supplemented animals. IL-6 cytokine levels were higher on days 15, 30 and 45 post-calving in supplemented animals compared to the control group (Table V).

\section{DISCUSSION}

The use of subcutaneous mineral supplementation in this study did not increase milk production, and it did not change milk composition, similarly to that observed by Machado et al. (2013), Ganda et al. (2016). These studies also used a commercial product containing minerals such as 
TABLE III

Mean and standard deviation of ketone bodies, total protein, albumin, globulin and glucose on days 3, 15, 30, 45 and 60 days post-calving of dairy primiparous cows supplemented with injectable minerals during the transitional period.

\begin{tabular}{|c|c|c|c|c|}
\hline Variable & Days & Supplemented group & Control group & P-value \\
\hline \multirow[t]{6}{*}{ Ketone bodies $(\mathrm{mmol} / \mathrm{L})^{*}$} & 3 & $0.70(0.1)$ & $0.78(0.3)$ & $>0.05$ \\
\hline & 15 & $0.88(0.3)$ & $0.85(3.0)$ & $>0.05$ \\
\hline & 30 & $0.63(0.1)$ & $0.81(0.1)$ & $<0.05^{*}$ \\
\hline & 45 & $0.65(0.05)$ & $0.86(0.2)$ & $<0.05^{*}$ \\
\hline & 60 & $0.63(0.1)$ & $0.92(0.09)$ & $<0.05^{*}$ \\
\hline & 3 & $5.5(0.5)$ & $4.6(0.6)$ & $<0.05^{*}$ \\
\hline \multirow[t]{5}{*}{ Total protein $(\mathrm{g} / \mathrm{dL})^{*}$} & 15 & $6.6(0.4)$ & $5.4(0.3)$ & $<0.05^{*}$ \\
\hline & 30 & $7.0(0.9)$ & $6.1(0.4)$ & $<0.05^{*}$ \\
\hline & 45 & $6.9(1.2)$ & $7.1(1.1)$ & $>0.05$ \\
\hline & 60 & $6.1(0.3)$ & $6.5(0.6)$ & $>0.05$ \\
\hline & 3 & $3.4(0.4)$ & $2.2(0.5)$ & $>0.05$ \\
\hline \multirow[t]{5}{*}{ Globulin $(\mathrm{g} / \mathrm{dL})^{*}$} & 15 & $4.3(0.5)$ & $3.2(0.5)$ & $<0.05^{*}$ \\
\hline & 30 & $4.8(0.7)$ & $3.7(0.3)$ & $<0.05^{*}$ \\
\hline & 45 & $4.7(0.5)$ & $4.7(0.4)$ & $>0.05$ \\
\hline & 60 & $4.1(0.6)$ & $4.3(0.6)$ & $>0.05$ \\
\hline & 3 & $2.1(0.5)$ & $2.4(0.4)$ & $>0.05$ \\
\hline \multirow[t]{5}{*}{$\operatorname{Albumin}(\mathrm{g} / \mathrm{dL})^{*}$} & 15 & $2.3(0.3)$ & $2.2(0.5)$ & $>0.05$ \\
\hline & 30 & $2.2(0.2)$ & $2.4(0.5)$ & $>0.05$ \\
\hline & 45 & $2.2(0.2)$ & $2.4(0.5)$ & $>0.05$ \\
\hline & 60 & $2.0(0.2)$ & $2.2(0.3)$ & $>0.05$ \\
\hline & 3 & $78.5(19.2)$ & $69.5(34.0)$ & $>0.05$ \\
\hline \multirow[t]{4}{*}{ Glucose $(\mathrm{mg} / \mathrm{dL})^{*}$} & 15 & $88.0(35.3)$ & $83.2(34.8)$ & $>0.05$ \\
\hline & 30 & $91.4(15.6)$ & $81.6(18.1)$ & $>0.05$ \\
\hline & 45 & $96.5(12.5)$ & $96.3(16.2)$ & $>0.05$ \\
\hline & 60 & $95.8(16.4)$ & $101.8(23.2)$ & $>0.05$ \\
\hline
\end{tabular}

"Significantly $(\mathrm{P}<0.05)$. "Student t-test.

selenium, copper and manganese, also present in the supplement used in our study. Another study conducted by Ramos et al. (2012) also did not find differences on milk production and composition, when tested a zinc, methionine, manganese, methionine, copperlysine and cobalt glucoheptonate based solution in grazing primiparous cows.
Therefore, based on these published studies, using different commercial products, we can verify that mineral supplementation is unable to change milk production and composition.

However, subcutaneousmineral supplementation showed a positive effect on the health of the udder of primiparous cows, since SCC was lower in 
TABLE IV

Mean and standard deviation of free radicals, catalase and superoxide dismutase on days 3, 15, 30, 45 and 60 days postcalving of dairy primiparous cows supplemented with injectable minerals during the transitional period.

\begin{tabular}{|c|c|c|c|c|}
\hline Variable & Days & Supplemented group & Control group & P-value \\
\hline \multirow{5}{*}{ Free radicals (U DCFA/mg) ${ }^{*}$} & 3 & $36.9(4.7)$ & $44.3(15.3)$ & $>0.05$ \\
\hline & 15 & $26.8(10.7)$ & $37.9(13.1)$ & $<0.05^{*}$ \\
\hline & 30 & $25.7(9.3)$ & $33.9(1.8)$ & $<0.05^{*}$ \\
\hline & 45 & $25.3(12.7)$ & $20.7(10.5)$ & $>0.05$ \\
\hline & 60 & $16.6(7.4)$ & $15.7(3.2)$ & $>0.05$ \\
\hline \multirow{5}{*}{$\begin{array}{l}\text { Superoxide dismutase (UI/mg } \\
\text { protein) }{ }^{*}\end{array}$} & 3 & $4.8(0.4)$ & $4.1(0.3)$ & $<0.05^{*}$ \\
\hline & 15 & $5.7(0.6)$ & $4.4(0.3)$ & $<0.05^{*}$ \\
\hline & 30 & $5.9(0.5)$ & $4.3(0.4)$ & $<0.05^{*}$ \\
\hline & 45 & $5.3(0.5)$ & $5.0(0.5)$ & $>0.05$ \\
\hline & 60 & $4.6(0.3)$ & $4.7(0.2)$ & $>0.05$ \\
\hline \multirow{5}{*}{ Catalase (nmol/mg protein) ${ }^{*}$} & 3 & $25.5(7.7)$ & $25.4(8.4)$ & $>0.05$ \\
\hline & 15 & $28.7(5.9)$ & $26.8(7.3)$ & $>0.05$ \\
\hline & 30 & $25.9(8.4)$ & $27.2(6.7)$ & $>0.05$ \\
\hline & 45 & $26.9(8.7)$ & $26.9(6.4)$ & $>0.05$ \\
\hline & 60 & $24.2(6.8)$ & $29.2(6.0)$ & $>0.05$ \\
\hline
\end{tabular}

"Significantly $(\mathrm{P}<0.05)$. "Student t-test.

animals supplemented on days 30,45 and 60 of the experiment. This result is due to the greater immune response activated by the minerals present in the supplement (mainly selenium and copper), since studies have shown that both minerals are linked to the reduction of SCC in primiparous and multiparous cows (Kruze et al. 2007, Salman et al. 2009, Machado et al. 2013). According to the literature, primiparous cows with mastitis caused by E. coli showed a peak for SCC only at $36 \mathrm{~h}$ when supplemented with copper sulfate in the peri-calving period, differently from those unsupplemented cows that had a peak at $18 \mathrm{~h}$, a decline at $24 \mathrm{~h}$ and another increase at $36 \mathrm{~h}$. In another study, researchers found that selenium (via diet or injectable) in primiparous grazing cows had a reduction in SCC in the first day to 28 days postcalving (Ceballos et al. 2010). However, in a study by Ramos et al. (2012), there was no reduction in the SCC of primiparous grazing cows until 90 days of lactation even when supplemented with minerals (zinc, manganese, copper and cobalt) in the diet. The divergence of results found in the literature can be explained by some factors such as: animals type, production system adopted, type of the diet provided, environment, herd health, composition and quantity of the product used, as well as by the way the mineral was supplied (organic or inorganic form).

Lower SCC may be related to immunological activation, which occurred in this study, since TNF, IL-1 and IL-6 levels were higher in cows supplemented after 15 days post injection of the minerals. According to the literature, cytokines are soluble mediators and assist in the regulation of the immune response, and are generally produced by macrophages, with TNF and IL-1 being the first to appear in an inflammatory response (Gengelbach 
TABLE V

Mean and standard deviation of cytokines (TNF, IL-1 and IL-6) on days 3, 15, 30, 45 and 60 days post-calving of dairy primiparous cows supplemented with injectable minerals during the transitional period.

\begin{tabular}{|c|c|c|c|c|}
\hline Variable & Days & Supplemented group & Control group & P-value \\
\hline \multirow{5}{*}{ TNF $(\mathrm{pg} / \mathrm{mL})^{*}$} & 3 & $10.0(0.9)$ & $8.7(0.7)$ & $>0.05$ \\
\hline & 15 & $14.9(1.7)$ & $11.2(0.9)$ & $<0.05^{*}$ \\
\hline & 30 & $14.2(1.5)$ & $11.7(0.8)$ & $<0.05^{*}$ \\
\hline & 45 & $12.9(2.2)$ & $12.6(1.9)$ & $>0.05$ \\
\hline & 60 & $12.4(1.3)$ & $12.5(2.4)$ & $>0.05$ \\
\hline \multirow{5}{*}{ IL-1 $(\mathrm{pg} / \mathrm{mL})^{*}$} & 3 & $3.78(0.58)$ & $3.73(0.49)$ & $>0.05$ \\
\hline & 15 & $5.95(0.71)$ & $4.26(0.64)$ & $<0.05^{*}$ \\
\hline & 30 & $5.90(0.57)$ & $4.70(0.54)$ & $<0.05^{*}$ \\
\hline & 45 & $5.28(0.38)$ & $5.02(0.5)$ & $>0.05^{*}$ \\
\hline & 60 & $4.73(0.6)$ & $5.22(0.51)$ & $>0.05^{*}$ \\
\hline \multirow{5}{*}{$\mathrm{IL}-6(\mathrm{pg} / \mathrm{mL})^{*}$} & 3 & $5.70(0.6)$ & $5.76(0.7)$ & $>0.05$ \\
\hline & 15 & $8.63(0.5)$ & $5.96(0.8)$ & $<0.05^{*}$ \\
\hline & 30 & $8.20(0.6)$ & $6.21(0.8)$ & $<0.05^{*}$ \\
\hline & 45 & $7.18(0.4)$ & $6.15(0.3)$ & $<0.05^{*}$ \\
\hline & 60 & $6.12(0.7)$ & $6.06(0.4)$ & $>0.05$ \\
\hline
\end{tabular}

*Significantly $(\mathrm{P}<0.05)$ * Student t-test.

and Spears 1998), as well as the main indicators of infection in the udder of cows. According to researchers, TNF participates in neutrophil chemotactic activity (Waller et al. 2003) and IL-1 during an inflammatory process regulates the expression of adhesion molecules and chemotaxis of neutrophils, as occurred in E. coli infection (Yamanaka et al. 2000), one of the main etiologic agents causing mastitis. The subcutaneous mineral supplementation in this study promoted a reduction of total seric ketone bodies (KB). This reduction in $\mathrm{KB}$ was only observed after 30 days of lactation, and we believe that it did not occur previously due to the high energy requirement that dairy cows have at this stage for milk synthesis, where the body increases the use of glucose for the synthesis of energy and milk production. This can be explained by the numerical reduction of blood glucose in the first 30 days of lactation within the same treatment when compared to other periods. After 30 days of lactation, a gradual increase in blood glucose concentration was observed in both groups, which may have occurred due to a higher intake of dry matter by the animals after the transition period. According to the literature, low blood glucose is due to increased tissue mobilization (mainly adipose tissue) as an attempt to increase available energy. Thus, with the mobilization of adipose tissue, a greater circulation of non-esterified fatty acids (NEFA) in the blood begins, that upon reaching the liver where are catalyzed. As a consequence, the ketone bodies are release into the bloodstream (Bühler et al. 2016). A recent study has found that a reduction on defense cells occurs in the transition period of Holstein cows in additon to increased concentrations of $\beta$-hydroxybutyrate (BHB) in the blood, which is related to placental retention (Moretti et al. 2016). High BHB concentration 
in the blood promotes lowers activity of the immune system, reducing the bactericidal action of neutrophils (Little et al. 2016) and this finding was confirmed in our study, where BHB was higher in non-supplemented cows, as well as globulin levels and cytokines were lower in the same animals.

Total protein levels increased with injectable mineral supplementation in cows as a result of high globulins. It should be noted that globulins have important role in the immune system, and their increase might be associated with immunological stimulation, since many of the minerals used act as cofactors and/or form part of the protein structure, such as copper and ceruloplasmin, which is a protein involved in distributing copper throughout the body (Overton and Yasui 2014). In the current study, albumin levels did not differ between groups, being this one of the main indicators of the protein status of a diet (González 2000).

During the transition period, several disorders can occur at different intensities, such as oxidative stress (Lykkesfeldt and Svendsen 2007), and therefore, in this study, mineral supplementation had a beneficial effect (increased antioxidant and reduced ROS), which minimized this oxidative stress in lactating cows. The subcutaneous mineral supplementation was able to stimulate the SOD enzyme increasing the activity since copper administered in cows act as a cofactor of this enzyme (Sharma et al. 2008). In similar studies using diet supplementation also reported an increase in SOD activity, when copper was one of the minerals supplemented (Spears and Weiss 2008, Sordillo and Aitken 2009, Machado et al. 2014).

The mineral supplementation in this study also increase cytokines levels such as TNF and IL-1 which was also reported in animals that received copper and molybdenum (Gengelbach and Spears 1998). The IL-1 cytokine is responsable for fever, hypotension, increased circulation of nitrogen oxide levels, recruitment of neutrophils and activation of $\mathrm{T}$ cells in the defense of the organism (Volp et al.
2010). IL-6 was also increased in this study, and it is an important cytokine to protect the animal against mastitis agents in dairy cows as described in the literature (Nakajima et al. 1997). Among the biomarkers of inflammation and oxidative status, selenium exerts a protective function and immunostimulant (Volp et al. 2010). In addition, IL-1, along with TNF- $\alpha$, stimulate IL- 6 production by smooth muscle cells and increase the expression of macrophages, and impair the immune response.

In conclusion, the subcutaneous mineral supplementation reduced somatic cell counts in the milk. This result is related to the mineral complex since it was able to minimize the oxidative stress in the post-calving period, as well as to improve animal health due to an estimulation of the immune system and the antioxidant effect by enzymatic activation. The subcutaneous mineral supplementation could be an alternative to minimize losses due to pathologies in cows in the transition period.

\section{REFERENCES}

ALI SF, LEBEL CP AND BONDY SC. 1992. Reactive oxygen species formation as a biomarker of methylmercury and trimethyltin neurotoxicity. Neurotoxicol 113(3): 637-648.

BÜHLER S, FRAHM J, TIENKEN R, KERSTEN S, MEYER U, HUBER K AND DÄNICKE S. 2016. Influence of energy level and nicotinic acid supplementation on apoptosis of blood leukocytes of periparturient dairy cows. Vet Immunol Immunopathol 179(1): 36-45.

CEBALLOS MA, BARKEMA HW, STRYHN H, WICHTEL JJ, NEUMANN J, MELLA A, KRUZE J, ESPINDOLA MS AND WITTWER F. 2010. The effect of selenium supplementation before calving on early-lactation udder health in pastured dairy heifers. J Dairy Sci 93(10): 46024612.

ESPOSITO G, IRONS PC, WEBB EC AND CHAPWANYA A. 2014. Interactions between negative energy balance, metabolic diseases, uterine health and immune response in transition dairy cows. Anim Reprod Sci 144(1): 60-71.

GANDA EK ET AL. 2016. Effects of injectable trace mineral supplementation in lactating dairy cows with elevated somatic cell counts. J Dairy Sci 99(9): 7319-7329.

GENGELBACH GP AND SPEARS JW. 1998. Effects of dietary copper and molybdenum on copper status, cytokine production, and humoral immune response of calves. J Dairy Sci 81(12): 3286-3292. 
GONZÁLEZ FHD. 2000. Use of metabolic profile to determine nutritional status in beef cattle. In: González FHD, Barcellos JO, Ospina H and Ribeiro LAO (Eds), Metabolic profile in ruminants: its use in nutrition and nutritional diseases. Porto Alegre, Brazil, UFRGS, p. 12.

KRUZE J, CEBALLOS A, STRYHN H, MELLA A, MATAMOROS R, CONTRERAS A, LEYAN V AND WITTEWER F. 2007. Somatic cell count in milk of selenium-supplemented dairy cows after an intramammary challenge with Staphylococcus aureus. J Vet Med A Physiol Pathol Clin Med 54(9): 478-483.

LITTLE MW, O'CONNELL NE, WELSH MD, BARLEY J, MEADE KG AND FERRIS CP. 2016. Prepartum concentrate supplementation of a diet based on mediumquality grass silage: Effects on performance, health, fertility, metabolic function, and immune function of low body condition score cows. J Dairy Sci 99(9): 7102-7122.

LYKKESFELDT J AND SVENDSEM O. 2007. Oxidants and antioxidants in disease: Oxidative stress in farm animals. Vet J 173(3): 502-511.

MACHADO VS, BICALHO MLS, PEREIRA RV, CAIXETA LS, KNAUER WA, OIKONOMOU G, GILBERT RO AND BICALHO RC. 2013. Effect of an injectable trace mineral supplement containing selenium, copper, zinc, and manganese on the health and production of lactating Holstein cows. Vet J 197(3): 451-456.

MACHADO VS, OIKONOMOU G, LIMA SF, BICALHO MLS, KACAR C, FODITSCH C, FELIPPE MJ, GILBERT RO AND BICALHO RC. 2014. The effect of injectable trace minerals (selenium, copper, zinc, and manganese) on peripheral blood leukocyte activity and serum superoxide dismutase activity of lactating Holstein cows. Vet J 200(2): 299-304.

MCCORD JM AND FRIDOVICH I. 1969. Superoxidase Dismutase. An enzymic function for erythrocuprein (hemocrupein). J Biol Chem 244(22): 6049-6055.

MORETTI P, PROBO M, CANTONI A, PALTRINIERI S AND GIORDANO A. 2016. Fluctuation of neutrophil counts around parturition in Holstein dairy cows with and without retained placenta. Res Vet Sci 107(2): 207-212.

MORGANTE M, BEGHELLI D, PAUSELL M, DALL'ARA P, CAPUCCELA M AND RANUCCI S. 1999. Effect of administration of vitamin $\mathrm{E}$ and selenium during the dry period on mammary health and milk cell counts in dairy ewes. J Dairy Sci 82(4): 623-631.

NAKAJIMA Y, MIKAMI O, YOSHIOCA M AND MOTOI Y. 1997. Elevated levels of tumor necrosis factor-alpha (TNF-alpha) and interleukin-6 (IL-6) activities in the sera and milk of cows with naturally occurring coliform mastitis. Res Vet Sci 62(2): 297-298.

NELSON DL AND KIESOW LA. 1972. Entalpy of the composition of hydrogen peroxide by catalase at $25^{\circ} \mathrm{C}$. Anal Biochem 49(4): 474-479.
OVERTON TR AND YASUI T. 2014. Practical applications of trace minerals for dairy cattle. J Anim Sci 92(3): 416-426.

RADAVELLI WM ET AL. 2016. Effect of lactation induction on milk production and composition, oxidative and antioxidant status, and biochemical variables. Comp Clin Pathol 25(5): 639-648.

RAMOS JM, SOSA C, RUPRECHTER G, PESSINA P AND CARRIQUIRY M. 2012. Effect of organic trace minerals supplementation during early postpartum on milk composition, and metabolic and hormonal profiles in grazing dairy heifers. Span J Agri Res 10(5): 681-689.

SALMAN S, KHOL-PARISINI A, SCHAFFT $\mathrm{H}$, LAHRSSEN-WIEDERHOLT M, HULAN WH, DINSE D AND ZENTEK J. 2009. The role of dietary selenium in bovine mammary gland health and immune function. Anim Health Res Rev 10(1): 21-34.

SHANKAR AH AND PRASAD AS. 1998. Zinc and immune function: the biological basis of altered resistance to infection. Am J Clin Nutr 68(3): 447-463.

SHARMA MC, JOSHI C AND DAS G. 2008. Therapeutic management of copper deficiency in buffalo heifers: Impact on immune function. Vet Res Commun 32(1): 49-63.

SOLDÁ NM ET AL. 2017. Injectable mineral supplementation to transition period dairy cows and its effects on animal health. Comp Clin Pathol 26(2): 335-342.

SORDILLO LM. 2016. Nutritional strategies to optimize dairy cattle immunity. J Dairy Sci 99(12): 4967-4982.

SORDILLO LM AND AITKEN SL. 2009. Impact of oxidative stress on the health and immune function of dairy cattle. Vet Immunol Immunopathol 128(1): 104-109.

SPEARS JW AND WEISS WP. 2008. Role of antioxidants and trace elements in health and immunity of transition dairy cows. Vet J 176(1): 70-76.

VOLP ACP, BRESSAN J, HERMSDORFF HHM, ZULET MA AND MARTÍNEZ JA. 2010. Selenium antioxidant effects and its link with inflammation and metabolic syndrome. Rev Nutr 23(4): 581-590.

WALLER KP, COLDTZ IG, LUN S AND OSTENSSON K. 2003. Cytokines in mammary lymph and milk during endotoxin-induced bovine mastitis. Res Vet Sci 74(1): 31 36.

WATHES DC, FENWICK M, CHENG Z, BOURNE N, LEWELLUN S, MORRIS DG, KENNY D, MURPHY J AND FITZPATRICK J. 2007. Influence of negative energy balance on cyclicity and fertility in the high producing dairy cow. Theriogenol 68(2): 232-241.

WINTERGERST ES, MAGGINI S AND HORNIG DH. 2007. Contribution of selected vitamins and trace elements to immune function. Ann Nutr Metab 51(2): 301-323.

YAMANAKA H, HISAEDA K, HAGIWARA K, KIRISAWA R AND IWAI H. 2000. ELISA for Bovine interleukin-1 receptor antagonist and its application to mastitic sera and whey. J Vet Med Sci 62(6): 661-664. 